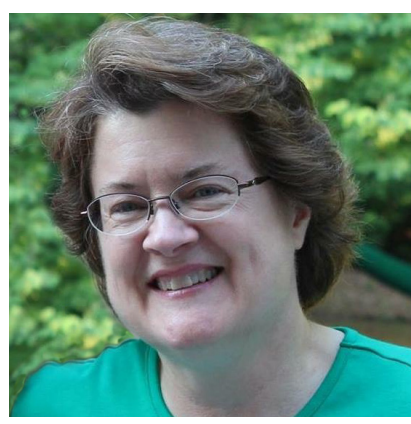

half hour's drive away. Then I started what I call "peeling the onion." Why was she in the wrong place? Did she move? When did she move? Was her voter registration updated correctly? I have to understand the voter's story before I can apply the law correctly. Virginia requires that you cast your ballot in the precinct where you are registered, so being in the right place is important.

She used to live in my precinct. When she moved, she updated her address with the Department of Motor Vehicles. Thanks to a new state law that took effect July 1 st, her new address was forwarded to the Office of Elections, which assigned her to the new precinct. She still lives at the new address, so the solution was simple: send her to the precinct where she is registered to vote.

I politely explained that she just needed to go home and vote at her new precinct. But she wouldn't do it. She refused to wait in line again even though lines were short by that time in the day. I was baffled. She had to drive home anyway, so going to the right precinct wouldn't be an inconvenience.

It was clear that I had lost this voter to something. She exceeded her personal reserve of patience, perhaps? I made my lastditch effort to give her a voting experience by offering a provisional ballot, gently hinting that it would take about the same amount of time as waiting in line again. To my dismay, she chose to cast the provisional ballot, which I knew wouldn't count. She disenfranchised herself by refusing to wait a few minutes at her own precinct.

I strive to say yes to voters-to find some way for every eligible voter to cast a ballot. It broke my heart to watch this voter throw away her vote.

\title{
BOOKS BY OUR MEMBERS
}

The Black and White Rainbow: Reconciliation,

Opposition, and Nation-building in Democratic South

Africa

Carolyn E. Holmes

University of Michigan Press

The Case for Identity Politics: Polarization, Demographic Change, and Racial Appeals

Christopher T. Stout

University of Virginia Press

China's Gilded Age: The Paradox of Economic Boom and Vast Corruption

Yuen Yuen Ang

Cambridge University Press

Disorienting Neoliberalism: Global Justice and the Outer Limit of Freedom

Benjamin L. McKean

Oxford University Press

The Far Right Today

Cas Mudde

Polity

Informing a Nation: The Newspaper Presidency of Thomas Jefferson

Mel Laracey

University of Michigan Press
International Aid and Democracy Promotion:

Liberalization at the Margins

Bann Seng Tan

Routledge

Power Without Knowledge: A Critique of Technocracy

Jeffrey Friedman

Oxford University Press

Turkey-West Relations: The Politics of Intra-alliance

Opposition

Oya Dursun-Özkanca

Cambridge University Press

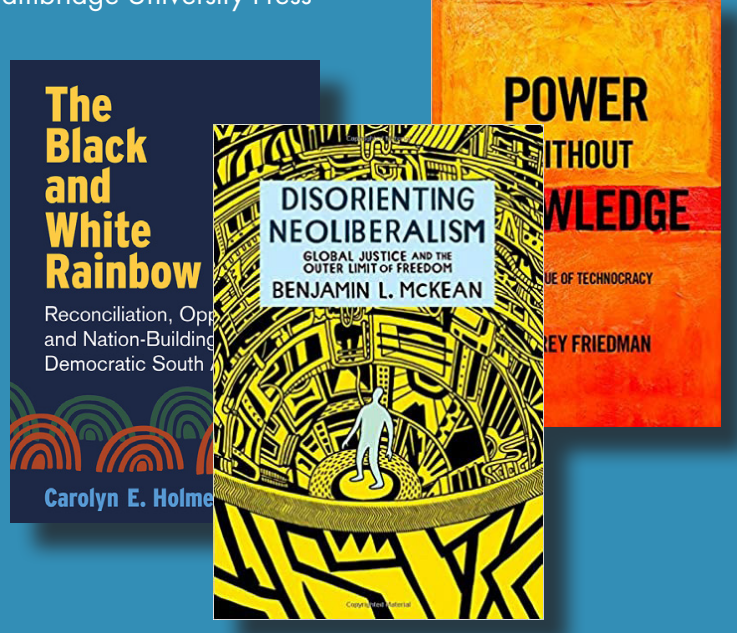

Tell us about your new publication! Email publications@apsanet.org 